\title{
CESAREAN SCAR ENDOMETRIOSIS: PRESENTATION OF ELEVEN CLINICAL CASES AND REVIEW OF THE LITERATURE
}

\author{
Gokhan DEMIRAL ${ }^{1}$, Fikret AKSOY ${ }^{2}$, Alp OZCELIK ${ }^{1}$, Burhan SABAN ${ }^{3}$, Mustafa KUSAK ${ }^{4}$, Ozgur EKINCI' , \\ Canan ERENGUL ${ }^{1}$ \\ ${ }^{1}$ General Surgery Clinic, Goztepe Training and Research Hospital, İstanbul, Turkey \\ 2 Private Maltepe Regional Hospital, İstanbul, Turkey \\ 3 Alucra State Hospital, Giresun, Turkey \\ 4 Taskopru State Hospital, Kastamonu, Turkey
}

\begin{abstract}
SUMMARY
Endometriosis is the presence of functioning endometrial tissue outside the uterine cavity. It can sometimes occur after obstetrical and gynecological surgeries. Scar endometriosis is rare and difficult to diagnose. This condition is often confused with other surgical patologies and preoperative diagnosis is rarely established. Medical treatment is not helpful. The patients required wide surgical excision of the lesion. In this study we are reporting eleven cases of abdominal wall endometriosis which were developed following cesarean section. The mean age of the patients was 28.3 and there were no any operation other than cesarean section. All masses were totally resected with one cm surgical margin. Whenever a female patient is presented with abdominal wall mass previous gynecological operations should be evaluated and endometriosis must be regarded between differential diagnosis.
\end{abstract}

Key words: Abdominal wall endometriosis, cesarean scar, surgical treatment

Journal of Turkish Society of Obstetrics and Gynecology, (J Turk Soc Obstet Gynecol), 2011; Vol: 8 Issue: 3 Pages: $209-13$

\section{SEZARYEN SKAR ENDOMETRIOZISI: ONBIIR OLGUNUN LITERATÜR EŞLIIĞINDE DEĞERLENDIRILMESI}

\section{ÖZET}

Endometriozis uterus kavitesi dışında fonksiyonel endometriyal doku varlığıdır. Jinekolojik veya sezaryen ameliyatları sonrası görülebilir. Skar endometriozisi oldukça nadir olup tanı konulması zordur. Diğer cerrahi patolojiler ile karıștırılabilen bu durumun tanısı ameliyat öncesinde nadiren konulur. Medikal yaklaşımın tedaviye yardımı yoktur. Lezyonun cerrahi olarak geniş eksizyonu gerekir. Bu çalışmada sezaryen ameliyatı sonrası gelişmiş on bir tane abdominal duvar endometriozis olgusunu sunuyoruz. Hastaların ortalama yaşı 28.3 olup sezaryen harici geçirilmiş operasyon öyküleri yoktu. Tüm hastalarda kitle en az bir cm cerrahi sınır korunacak şekilde total eksizyonla çıkarıldı. Batın ön duvarında kitle ile başvuran kadın hastalarda geçirilmiş jinekolojik ameliyatlar iyi sorgulanmalı ve ayırıcı tanılar arasında mutlaka endometriozis düşünülmelidir.

Anahtar kelimeler: abdominal duvar endometriozisi, cerrahi tedavi, sezaryen skarl

Türk Jinekoloji ve Obstetrik Derneği Dergisi, (J Turk Soc Obstet Gynecol), 2011; Cilt: 8 Sayl: 3 Sayfa: 209-13

Address for Correspondence: Gökhan Demiral. Dr. Mithat Süer sok. Hidayet Sitesi C B1 D: 18, Erenköy, Kadıköy, İstanbul Phone: + 90 (216) 5664000

e-mail: drgokhandemiral@yahoo.com

Received: 10 March 2010, revised: 30 July 2010, accepted: 09 August 2010, online publication: 06 September 2010 


\section{INTRODUCTION}

Endometriosis is the presence of the endometrial tissue and stroma outside the uterus. Common sites for the endometriosis include ovaries, uterine ligaments, rectovaginal septum and pelvic peritoneum ${ }^{(1)}$. It may rarely seen also extrapelvic sites including the lungs, spleen, intestines, gall bladder, stomach, kidneys, abdominal wall, extremities, central nervous system, spinal cord, nasal mucosa, breast, cervix, vagina and vulva $^{(1)}$. Abdominal wall endometriosis (AWE) usually occurs after invasive surgical procedures especially after cesarean section. Endometriosis occurs in \% 15 of the menstruating females. Symptoms are dysmenorrhea, infertility and menstrual irregularities ${ }^{(2)}$. Most common symptom of the AWE is the nonreductable painful mass that is cyclic and related with the menstruation ${ }^{(3,4)}$. In this study patients are retrospectively evaluated which were presented with a mass on the cesarean incision area.

\section{PATIENTS}

In this report eleven patients who were presented in our clinic with swelling and pain around incision area on abdominal wall after cesarean operation between 2004-2009 years are retrospectively evaluated. All the patients were operated and the specimens were patologically reported as AWE.

The ages, localisation and size of the masses, preoperative diagnostic techniques (Figure 1), previous cesarean operation times and prediagnosis were evaluated (Table I). In all of the patients the pain was cyclic and increasing with the menstruation excluding three of them. In these three cases ultrasonography (USG) was reported as lipoma that was irregular in shape and hyperechogen. Other eight patients' s ultrasonography was reported as irregular in shape, heterogenous, solid and hypoechoic mass lesion.

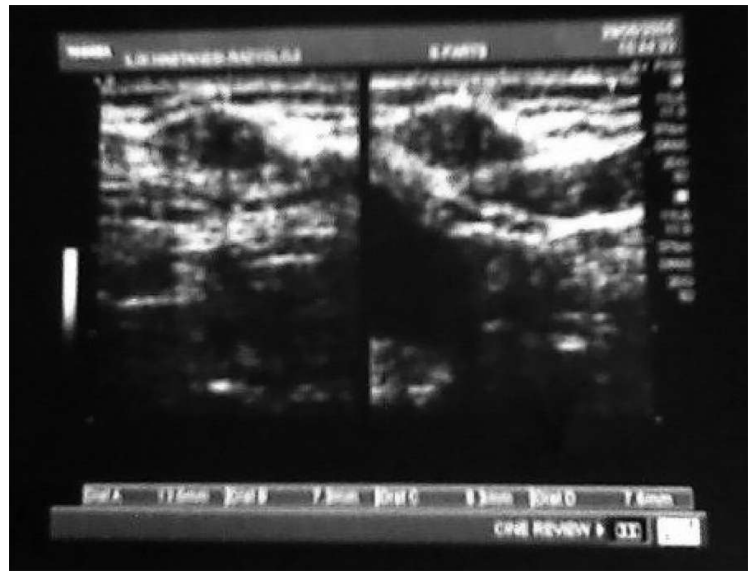

Figure 1: Ultrasonograpic imaging of endometriosis.

The masses on the abdominal wall were surgically resected widely with a minimum $1 \mathrm{~cm}$ surgical border. The facial defects repaired primarily with prolen suture material. In three of the patients with large fasial defects extra polytetraflouroethylen mesh were applied. No drain was used. They were discharged at the postoperative first day and recommended for gynecological evaluation for the possibility of concomitant pelvic endometriosis. On their control examination it is observed that none of them diagnosed as pelvic endometriosis.

Table 1: Retrospective evaluation of eleven patients.

\begin{tabular}{|c|c|c|c|c|c|c|}
\hline Patient & Age & Localisation & $\begin{array}{l}\text { Size of } \\
\text { the mass }\end{array}$ & $\begin{array}{l}\text { Beginning of } \\
\text { the symptoms }\end{array}$ & $\begin{array}{l}\text { Previous Cesarean } \\
\text { operations }\end{array}$ & $\begin{array}{l}\text { Estimated diagnosis } \\
\text { preoperatively }\end{array}$ \\
\hline 1 & 30 & Right lateral side of incision & $3 \times 2 \times 2 \mathrm{~cm}$ & 5 year & $3-8$ years ago & Endometriozis \\
\hline 2 & 26 & Left lateral side of incision & $3 \times 3 \times 2 \mathrm{~cm}$ & 3 year & 4-6 years ago & Endometriozis \\
\hline 3 & 27 & Right lateral side of incision & $4 \times 4 \times 3 \mathrm{~cm}$ & 2,5 year & 6 years ago & Endometriozis \\
\hline 4 & 29 & Right lateral side of incision & $3 \times 2 \times 2 \mathrm{~cm}$ & 1,5 year & 4 years ago & Lipom \\
\hline 5 & 28 & Right $2 / 3$ of incision & $4 \times 3 \times 3 \mathrm{~cm}$ & 1 year & 3 years ago & Endometriozis \\
\hline 6 & 27 & Left lateral side of incision & $3 \times 2 \times 2 \mathrm{~cm}$ & 2 year & 4 years ago & Endometriozis \\
\hline 7 & 33 & Middle of incision & $2 \times 2 \times 2 \mathrm{~cm}$ & 2 year & 2-4 years ago & Lipom \\
\hline 8 & 31 & Right lateral side of incision & $4 \times 4 \times 3 \mathrm{~cm}$ & 4 year & $2-4-6$ years ago & Endometriozis \\
\hline 9 & 26 & Left lateral side of incision & $4 \times 2 \times 2 \mathrm{~cm}$ & 8 nonths & 2 years ago & Lipom \\
\hline 10 & 23 & Middle of incision & $3 \times 3 \times 3 \mathrm{~cm}$ & 1,5 year & 3 years ago & Endometriozis \\
\hline 11 & 32 & Right $2 / 3$ of incision & $2 \times 2 \times 1 \mathrm{~cm}$ & 4 year & 3-7 years ago & Endometriozis \\
\hline
\end{tabular}




\section{DISCUSSION}

There are different theories on the pathogenesis of the endometriosis. Endometrial components get through abdominal cavity from uterine tubes during menstruation. Although the implantation and proliferation into the different tissues and organs of the endometrial cells by lymphatic and hematogenous metastasis, coelomic metaplasia and genetic tendency are some of the theories the occurence of the scar endometriosis is largely explained with the theory of iatrogenic transportation of the endometrial tissue during surgical operations $(3,4)$.

In some of the cases AWE may invase into the facial tissue and in these patients facial around the mass lesion must be resected. Prevention can be achieved with careful attention to the surgical detail during the cesarean operations or invasive uterine procedures. Also the dissection area and the wound should be washed and irrigated vigorously with saline solutions before closure ${ }^{(5)}$.

The incidence of the AWE after cesarean operation is $\%$ 0.03-0.4 and after hysterectomy is $\% 1-2^{(6,7)}$. On the other hand endometriosis can occur after fallopian tube operations, appendectomy, episiotomy, laparoscopic interventions, amniocentesis and inguinal hernioraphy (8). Symptoms may occur three months to 10 years after surgery $(9)$. In our patients symptoms initiated eight months to five years after surgery. Four of them were undergone second and one of them third cesarean operation.

The most common symptom is cyclic and painful nonreductable mass around the scar tissue which waxed and waned with menstrual period ${ }^{(4,11)}$. All of our patients were presented with swelling in the old incision area. Also they had complaints of cyclic pain relevant with menstruation except of three of them.

Dysmenorhea, pelvic pain and infertility should be evaluated in the medical history of these patients because pelvic endometriosis can be seen concomitantly up to 25 $\%$ of these ${ }^{(11,12)}$. In the literature the disease sometimes presented as painless mass probably dependent on the size and the location site ${ }^{(12)}$. In our study all of the patients presented with painful mass.

The differential diagnosis of the AWE are lipoma, hematoma, sebaceous cyst, suture granuloma, incisional hernia, desmoid tumor, sarcoma, lymphoma, primary and metastatic tumors ${ }^{(3)}$. These patients mostly refered to general surgeons probability due to complaints relavant to mass. In the literature although some diagnostic procedures have been used in a study the correct preoperative diagnosis was made in only 2 of 10 patients ${ }^{(13)}$

Blanco et al described a study that the inguinal hernia, incisional hernia and abdominal wall tumors were estimated as prediagnosis ${ }^{(3)}$. Beside the increasing frequency of AWE incidence with a careful medical history correct estimation of the prediagnosis will be increase. In our study only three patients were estimated as lipoma and the others were diagnosed correctly. It is remarkable in these three patients that the pain was not related with the menstruation.

Due to lack of metaanalysis on this subject it is not clear that which incisions or operations carry the most risk of AWE patients. One study indicate that most cases of endometriosis occur after midline abdominal laparotomy(14). In another study $2 \%$ of midline laparotomies incidental to second trimester abortion were associated with later devolepment of endometriosis. In a survey of occurences of surgical scar endometriosis, 19 out of 24 cases resulted from cesarean section incisions ${ }^{(14)}$. Cesarean incisions were also applied to all 8 patients in another report ${ }^{(2)}$. Pfannenstiel incision as opposed to the midline incision is the most commonly reported type ${ }^{(1,6)}$. Pfannenstiel incisions contain a higher risk of endometriosis than do midline incisions, probability due to the wide dissection planes, difficult tissue irrigation and much more contamination. Nowadays over indications of Cesarean sections also may increase the AWE cases.

There is not a proven radiologic study for diagnosis or evaluation of AWE. However USG, computed tomography (CT) and magnetic resonance imaging (MRI) supply adequate information about the size, location and depth of the mass(15). On USG an endometriosis will most likely present as a vesicular hypoechoic mass and appearance can change dependent on menstruation cycle. USG can differantiate between a solid or cystic mass ${ }^{(15)}$. CT can localize the extent and depth of the lesion. MRI is much more helpful to evaluate the relations of mass with the surrounding muscle and subcutanous tissue ${ }^{(16)}$. However contents of hemosiderin pigments may leads to a low resolution in large lesions. Fine needle aspiration biopsy (FNAB) can be a reliable technique for evaluation and definitive diagnosis of AWE. It can detect the presence of 
endometrial tissue, endometrial stroma and hemosiderin pigment ${ }^{(5)}$. However recently in a four patient study it is reported that none of them diagnosed correctly with FNAB(17). Incisional biopsy should be avoided because of the probability of further transportation of endometrial components along adjacent tissues $(3,17)$. USG was performed in our all patients preoperatively. The masses of third, seventh and ninth patients were reported as hyperechogenic lipomas. Others were reported as regular shaped, heterogenous, solid, hypoechoic masses. In these eight patients USG was performed in much more painful days which was menstruation period. On the contrary others were performed in the middle of menstruation period. We suppose that the preoperative diagnosis of mass may be associated with the timing of USG.

Surgical wide excision of the lesion with $1 \mathrm{~cm}$ surgical margin is still the only effective treatment of choice (2). Medical treatment with combined oral contraceptives, progestin, danazol, gestinone, GnRH analogous and anastrasole are effective in pelvic endometriosis but not in AWE. They may only slightly relieve the symptoms and in a short time patients undergo surgical resection(18).

Because of the recurrences these patients should be taken into near follow up programme. Before the closure of the incision dissection area and the wound should be washed and irriageted carefully with saline solutines intraoperatively. There is a high risk of endometrial carcinoma in unexcised endometriosis. Therefore in any case of recurrence reexcison should be performed ${ }^{(19)}$.

Referral to a gynecologist is not always necessary. But patients who are infertile or who have other symptoms of pelvic endometriosis should always be recommended to a gynecologist after surgical resection ${ }^{(6)}$.

In conclusion previous gynecological operations should be evaluated in patients presented with a mass on the abdominal wall. AWE must be thought among the differential diagnosis. Other probable reasons also should be considered. Diagnostic toolls like USG and CT should be used. FNAB is also encouraged if necessary. Medical treatment is not effective therefore wide surgical excision should be applied.

Because of the recurrences patients should be taken into near follow up and control programme.

\section{REFERENCES}

1. Chun JT, Nelson HS, Maull KI. Endometriosis of the abdominal wall. Southern Medical Journal 1990; 83: 1491- 2.

2. Patterson GK, Winburn GB. Abdominal wall endometriosis: Report of eight cases. Am Surg 1999; 65: 36- 9.

3. Blanco RG, Parithivel VS, Shah AK, Gumbs MA, Schein M, Gerst PH. Abdominal wall endometriomas. Am J Surg 2003; 185: 596- 8 .

4. Healy JT, Wilkinson NW, Sawyer M. Abdominal wall endometrioma in a laparoscopic trocar tract: A case report. The American Surgeon. 1995; 61: 962- 3 .

5. Kocakuşak A, Arpinar E, Arikan S, Demirbag N, Tarlaci A, Kabaca C. Abdominal wall endometriosis: A diagnostic dilemma for surgeons. Med Princ Pract 2005; 14: 434- 7.

6. Singh KK, Lessels AM, Adam DJ, Jordan C, Miles WF, Macintyre IM, et al. Presentation of endometriosis to general surgeons: A 10 year experience. Br J Surg 1995; 82: 1349- 51.

7. Firilas A, Soi A, Max M. Abdominal incision endometriomas. Am Surg 1994; 60: 259- 61.

8. Thylan S. Re: Abdominal wall endometrioma in a laparoscopic trocar tract: A case report. Am Surg 1996; 62: 617

9. Goel P, Sood SS, Dalal A. Cesarean scar endometriosis-Report of two cases. Indian J Med Sci 2005; 59: 495- 8 .

10. Cerçi SS, Cerçi C, Balcı TA, Kömek H, Kılınç N. Abdominal wall endometriosis imaged with sintigraphy: report of a case. S.D.Ü. Tıp Fak Derg 2005; 12: 57- 60.

11. Matthes G, Zabel DD, Nastala CL, Shestak KCl. Endometrioma of the abdominal wall following combined abdominoplasty and hysterectomy: Case report and review of the literature. Ann Plast Surg 1998; 40: 672- 5

12. Bachir JS, Bachir NM. Scar endometrioma: Awareness and prevention. WMJ 2002; 101: 46- 9.

13. Nirula R, Greaney GC. Incisional endometriosis: An underappreciated diagnosis in general surgery. J Am Coll Surg 2000; 190: 404- 7 .

14. Koger KE, Shatney CH, Hodge K. Surgical scar endometrioma. Surg Gynecol Obstet 1993; 177: 243- 6.

15. Roberge RJ, Kantor WJ, Scorza L. Rectus abdominus endometrioma. Am J Emerg Med 1999;17:675-7.

16. Bis KG, Vrachliotis TG, Agrawal R, Shetty AN, Maximovich A, Hricak H. Pelvic endometriosis: MR imaging spectrum with laparoscopic correlation and diagnostic pitfalls. Radiographics 1997; 17: 639- 55.

17. Dwivedi AJ, Agarwal SN, Silva YJ. Abdominal wall endometriomas. Dig Dis Sci 2002; 47: 456- 61 .

18. Rivlin ME, Das SK, Patel RB, Meeks GR. Leuprolide acetate in the management of ceseraen scar endometriosis. Obstet 
Gynecol 1995; 85: 838- 9.

19. Wasfie T, Gomez E, Seon S. Abdominal wall endometrioma after ceseraen section: a preventable complication. Int Surg 2002; 87: 175- 7 . 